\title{
Optimization of water for fruit trees by a computerized irrigation system
}

\author{
R. Assaf' ${ }^{1}$ I. Levin ${ }^{1}$ and B.A. Bravdo² \\ 1 Agricultural Research Organization Volcani Center, Bet-Degan, Israel; \\ 2 Department of Horticulture, Faculty of Agriculture, Rehovot, The Hebrew University of Jerusalem, Israel
}

(received 3 March 1988, accepted 12 February 1989)

Summary - Recent technological development enables us to control the root environment in terms of water and volume of the irrigated soil. Electrotensiometers were mounted at a constant depth and distance in relation to the drippers in a high yielding apple orchard. These electrotensiometers were connected to a computer capable of operating the irrigation according to programmable threshold soil matric potential (SMP) levels. The SMP control determined the water content and the irrigated soil volume and possibly the size of the active root system. This method enabled water to be supplied at the rate of consumptive use of the trees, and should eliminate water and mineral percolation to soil layers below the active root zone.

During 3 consecutive years treatments consisting of high and low SMP threshold levels and a common commercial irrigation regime according to pan evaporation coefficients were applied. The control of SMP may stimulate root production in a limited volume of soil and thereby induce physiological root restriction effects such as reduction of vegetative to reproductive growth ratio. The main result obtained was a decrease in vegetative growth without impairing crop load (the ratio of reproductive to vegetative growth $-\mathrm{kg}$ fruit/ $\mathrm{cm}^{2}$ trunk growth) and fruit size in the low SMP treatment irrigated with $213 \mathrm{~mm}$ less water than the treatment according to pan evaporation. It was concluded that this system of irrigation may reduce the size of the trees, and thereby increase light penetration, improve fruit quality, and lower the cost of production. This method will permit the planting of economically successful high density orchards.

trickle irrigation - soil matric potential - electrotensiometer - apple yield and growth - automatic computerized irrigation

Résumé - Irrigation automatique informatisée, et optimisation hydrique pour les arbres fruitiers. Les technologies nouvelles, récemment développées, permettent de contrôler les conditions dans la zone racinaire, en particulier la teneur en eau et potentiellement les concentrations de minéraux ainsi que le volume irrigué du sol.

Des électrotensiomètres mesurant le potentiel matriciel du sol sont installés à une profondeur et une distance constante des goutteurs dans un verger en production. Ils sont reliés à un ordinateur destiné à piloter l'irrigation en fonction de seuils de potentiel matriciel du sol préprogrammés.

Le contrôle du potentiel hydrique du sol permet d'agir sur le contenu en eau du sol, et ainsi, sur le développement du système racinaire actif. Cette méthode permet de satisfaire en permanence la consommation d'eau et de minéraux par les arbres, sans avoir de pertes dans le sol en dessous de la zone racinaire.

Pendant 3 années consécutives, nous avons appliqué de cette manière 3 traitements de régime hydrique : les irrigations à un niveau haut de potentiel matriciel du sol et à un niveau bas ont été comparées à la méthode de conduite de l'irrigation habituelle basée sur l'évaporation d'un bac classe $A$. Dans cet essai, les récoltes de pommes sont élevées et de qualité.

Le principal résultat obtenu dans cette expérimentation est l'obtention d'une réduction du développement végétatif des arbres dans le traitement de bas niveau de potentiel matriciel, avec $213 \mathrm{~mm}$ d'eau en moins que dans le traitement basé sur le bac classe $A$, sans influencer la charge en fruits des arbres (rapport de la croissance reproductive à la croissance végétative en $\mathrm{kg}$ de pommes $/ \mathrm{cm}^{2}$ de croissance de tronc) et le calibre des fruits.

Ce système d'irrigation réduit la croissance des arbres, mais il améliore la pénétration de la lumière et la qualité des fruits tout en économisant les charges de production.

Cette méthode devrait permettre dans l'avenir des plantations de plus haute densité.

irrigation localisée - goutteur - potentiel matriciel du sol - électrotensiomètre - pommiers - récolte et croissance - irrigation automatique informatisée 


\section{Introduction}

Optimization of crop production requires application of optimal environmental conditions to the roots as well as to the canopy. High production in crops such as tomatoes is presently achieved in greenhouses under controlled conditions. It is difficult to achieve complete control under field conditions, but recent developments in irrigation technologies have enabled the root environment to be controlled in terms of root volume, root aeration, and concentrations of minerals and water at various stages of growth and development. Once the optimal concentrations of minerals are determined, application at the rate of consumptive use through fertigation systems is possible. It should be borne in mind that the application of water and minerals at the rate of consumptive use can be implemented at rates according to the grower's desire. For example, once it has been decided to maintain a certain soil water content in the root zone, frequent application of water for maintaining it will result in irrigation according to the rate of consumptive use. The plant will then adjust its growth, leaf area and productivity to that soil water potential in the root zone which determines the availability of the soil water. Such an adjustment has been well demonstrated in drip irrigated apples (Assaf et al., 1974; Proebsting et al., 1977; Levin et al., 1979; Middleton et al., 1979; Elfving, 1982).

Drip irrigation is the most appropriate method for irrigating at the rate of consumptive use because of its slow rate of water emission. This irrigation method also enables soluble fertilizers to be applied through the irrigation water at the rate of consumptive use. In this case, the rate of application is adjusted so as to maintain a constant nutrient concentration in the root zone. A constant gradient of minerals is then formed within the irrigated soil volume. For example, potassium and phosphorus concentrations decrease whereas nitrate- $\mathrm{N}$ increase as a function of the distance from the emitter (Phene and Beale, 1976; Bravdo and Hepner, 1987). The densely developed root system efficiently occupies the restricted irrigated soil volume, and therefore the concentrations at the immediate vicinity of the roots resemble the concentrations of the minerals in the soil or soil solution sampled at diiferent depths and distances from the emitters (Richards, 1983). In the present paper we report results of an irrigation experiment in apples where a soil matric potential (SMP) was maintained at 2 levels using electrotensiometers as SMP sensors for a continuous control of water application by a computer.

\section{Material and Methods}

The experiment was conducted at Ayelet Hashahar in the southern part of the Hula Valley, Israel. The soil is a brown alluvial vertisol, uniform down to $1.5 \mathrm{~m}$, with an underlying layer of calcareous gravel. The soil composition is $69 \%$ clay, $25 \%$ silt and $6 \%$ sand; $\mathrm{pH}$ (in water) is 7.6 , bulk density 1.4 , field capacity $39 \%$ and wilting point $26 \%$ (by weight).

Golden Delicious apples on selected Hashabi rootstock (medium vigor), were planted in 1971 at $4 \times 3 \mathrm{~m}$ spacing. Additional pollinators were cvs Orleans and Granny Smith. Fertilizers were applied through the irrigation system at ca. $320 \mathrm{~kg} \mathrm{~N} \mathrm{ha-1,} 450 \mathrm{~kg} \mathrm{~K} \mathrm{ha}^{-1}$ and $5 \mathrm{~kg} \mathrm{ha}^{-1}$ of Sequestrene $\mathrm{H} 138$ annually. Thirty $\mathrm{kg} \mathrm{P}$ $\mathrm{ha}^{-1}$ were applied once in 3 years. The drip irrigation system was carried out by one lateral per tree row with $8 \mathrm{l} / \mathrm{h}$ discharge rate drippers placed $15 \mathrm{~m}$ apart. An automated irrigation was actuated by electrotensiometers for controlling the SMP levels in the root zone. This irrigation system was connected to a computerized control unit (PCU 10, Motorola, Israel). Irrigation in each treatment was controlled by 4 electrotensiometers, one per replicate (AMI Ltd., Israel and Irrometer Co., USA). They were placed at $35 \mathrm{~cm}$ depth and 30 $\mathrm{cm}$ distance from the dripper. This position was selected after preliminary trials. The electrotensiometers produced continuous signals proportional to the pressure inside the tensiometers. In addition, regular tensiometers were placed at similar distances and depths from the drippers to enable monitoring the automatic SMP readings of the electrotensiometers. Good agreement was found between these manual readings on the regular tensiometers and the computer-recorded readings of the electrotensiometers (data not shown).

The data obtained from the 4 electrotensiometers were averaged by the computer for each treatment. Irrigation was applied by on and off pulses of $10 \mathrm{~min}$ in order to minimize overshooting of the SMP level following the off signals. The computers program chart of the system is presented in Fig. 1.

Three treatments were arranged at random in 4 blocks with 14 trees per replicate:

Treatment 1 (T1) : irrigation applied at $-10 \mathrm{kPa}$ threshold;

Treatment 2 (T2) : irrigation applied at $-15 \mathrm{kPa}$ threshold;

Treatment 3 (T3) : daily irrigation according to class A pan evaporation coefficient.

The coefficients varied throughout the season as follows : from bud burst to fruit set 0.5 , from fruit set until the fruit size reached a $3-\mathrm{cm}$ diameter 0.7 , from $3-\mathrm{cm}$ diameter to harvest 1.0 and after harvest 0.5 . All the irrigation treatments started in 1982 but data could not be collected due to reasons beyond our control. The yield in each treatment replicate was weighed and the fruit size distribution was recorded.

The circumference of each tree trunk was measured with a tape at a fixed point, $20 \mathrm{~cm}$ above the ground each winter.

\section{Results and Discussion}

The SMP was kept around $-10 \mathrm{kPa}$ in $\mathrm{T} 1$ and around $-15 \mathrm{kPa}$ in T2. Variation of $\approx 5 \mathrm{kPa}$ around the average was apparent in both treat- 


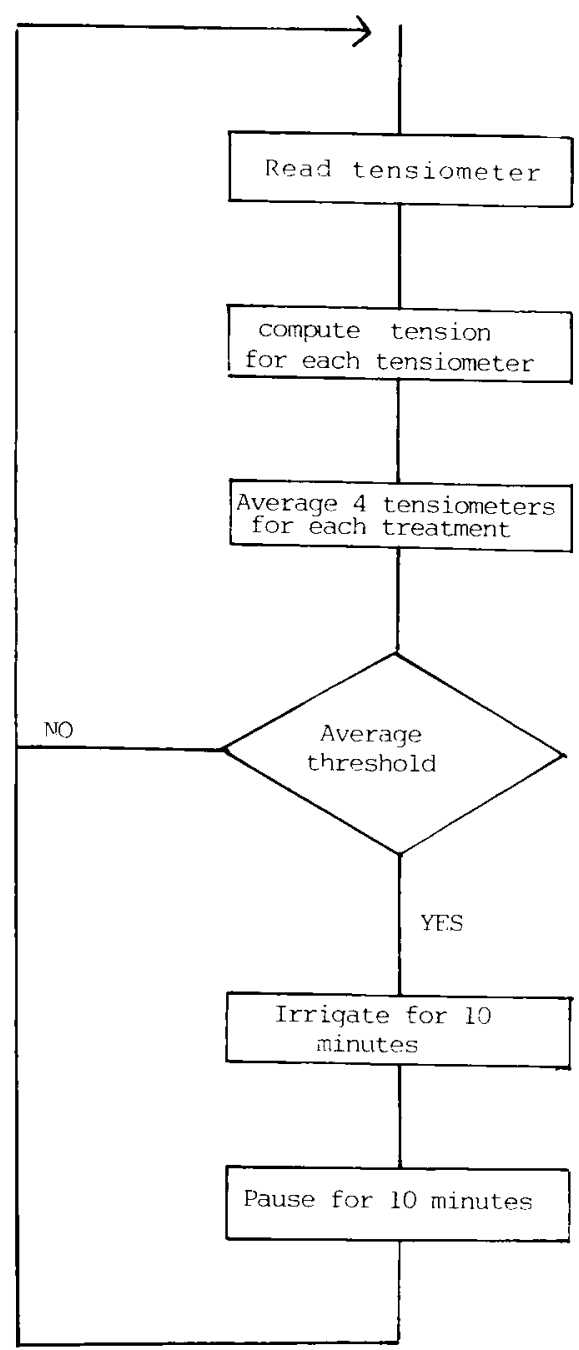

Fig. 1. Sensor operation chart.

ments (Figs. 2a, 2b). This was due mainly to overshooting caused by the limitation imposed by the hydraulic conductivity of the soil. The seasonal water amounts applied were higher in the treatment irrigated according to pan evaporation coefficients than in the $-10 \mathrm{kPa}$ threshold, whereas the $-15 \mathrm{kPa}$ threshold treatment received even smaller amounts of irrigation water (Table l). The yields of all treatments were relatively high, the fruits were large and their quality was good throughout the experimental period. In spite of the differences in water amounts applied during the 3 years of the experiment, only T2 $(-15 \mathrm{kPa}$ threshold) was significantly lower in yields and growth compared to the rest of the treatments (Tables I, II IV). However, the differences were significant only for the averages taken over 3 years and not for the individual year. This may be explained by the slow response of fruit trees to such treatments and variability in the experimental orchard. The differences were reflected in both fruit number and fruit size. Although the results for 1982 are not presented here due to difficulties described above, it should be mentioned that the treatments were applied during that year. The yields obtained in 1983 were lower in T2 $(-15 \mathrm{kPa}$ threshold treatment) than in the others with less fruits and smaller size of the fruits (Table II). The reduction in the number of fruits was due to the previous year's effect, whereas that of the fruit size (Table III) was probably due to water shortage (results not published here). In 1984, which was an "off" year, the yields were reduced by $40-50 \%$ in the $-10 \mathrm{kPa}$ threshold and in the treatments irrigated according to pan evaporation coefficient, whereas the reduction in yield in the $-15 \mathrm{kPa}$ irrigation treatment was only $20 \%$ (Table II). The yields as well as the fruit size in all 3 treatments were similar in 1984 (Tableau II, III).

Table I. Amount of water applied over 3 experimental years.

\begin{tabular}{lllll}
\hline Treatment & $\begin{array}{l}1983 \\
(\mathrm{~mm})\end{array}$ & $\begin{array}{l}1984 \\
(\mathrm{~mm})\end{array}$ & $\begin{array}{l}1985 \\
(\mathrm{~mm})\end{array}$ & $\begin{array}{l}\text { Average } \\
(\mathrm{mm})\end{array}$ \\
\hline 1 & 741 & 725 & 722 & 729 \\
2 & 638 & 689 & 617 & 648 \\
3 & 889 & 908 & 736 & 861 \\
\hline
\end{tabular}

Table II. Apple yield over 3 experimental years.

\begin{tabular}{lllll}
\hline Treatment & $\begin{array}{l}1983 \\
(\mathrm{Mg} / \mathrm{ha})\end{array}$ & $\begin{array}{l}1984 \\
(\mathrm{Mg} / \mathrm{ha})\end{array}$ & $\begin{array}{l}1985 \\
(\mathrm{Mg} / \mathrm{ha})\end{array}$ & $\begin{array}{l}\text { Average } \\
1983-1985\end{array}$ \\
\hline & & & & \\
1 & 144 & 72 & 90 & $102 \mathrm{a}$ \\
2 & 89 & 71 & 67 & $76 \mathrm{~b}$ \\
3 & 148 & 89 & 87 & $108 \mathrm{a}$ \\
& & & & LSD $=1.2$
\end{tabular}

Significant differences are indicated by the by letters $a, b$; $P=0.05$.

Table III. Fruit size distribution (diameter, weighted average).

\begin{tabular}{llll}
\hline Treatment & $\begin{array}{l}1983 \\
(\mathrm{~cm})\end{array}$ & $\begin{array}{l}1984 \\
(\mathrm{~cm})\end{array}$ & $\begin{array}{l}1985 \\
(\mathrm{~cm})\end{array}$ \\
\hline 1 & & & \\
2 & $6.92 \mathrm{a}$ & 6.20 & 6.64 \\
3 & $6.47 \mathrm{~b}$ & 6.14 & 6.61 \\
& $6.87 \mathrm{a}$ & 6.35 & 6.63 \\
& LSD $=3.1$ & & \\
\hline
\end{tabular}

Significant differences are indicated by the letters $a, b$. 


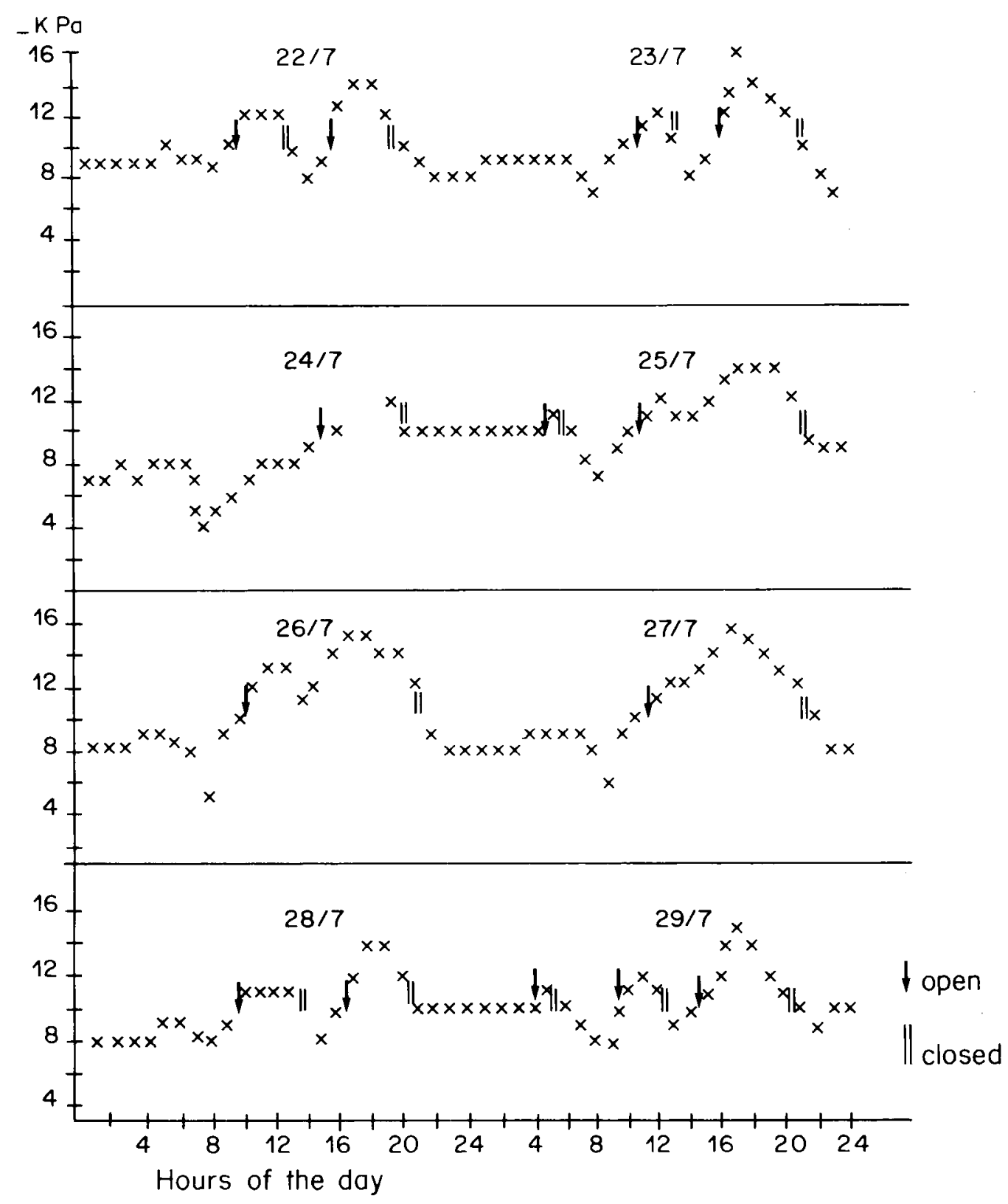

Fig. 2a. Diurnal soil matric potential (SMP) in T1 in 1985.

In 1985 the yield of the $-10 \mathrm{kPa}$ irrigation threshold and the pan evaporation coefficient treatments increased, whereas that of the $-15 \mathrm{kPa}$ did not (Table II). However, fruit size was similar in all 3 treatments. The vegetative growth of the trees as represented by the trunk cross-sectional area increment in 1983 was slightly greater in the plots irrigated according to pan evaporation coefficient than in the $-10 \mathrm{kPa}$ threshold treatment. However, the vegetative growth of the trees in the $-15 \mathrm{kPa}$ treatments was even smaller (Table IV).

The trunk cross-sectional area increment in 1984 was relatively smaller in all treatments.
However, the reduction in growth in the $-15 \mathrm{kPa}$ (T2) threshold irrigation treatment was $17 \%$ as compared to 1983, whereas reduction in the other 2 treatments was $>30 \%$. The trunk crosssectional increment in 1985 was again higher than in 1984 in all treatments. In the $-10 \mathrm{kPa}$ threshold (T1) and in the pan evaporation coefficient treatment (T3) the increments were similar, whereas the growth in the $-15 \mathrm{kPa}$ (T2) treatment was lower than both (T1 and T3) by $\approx 13 \%$ (Table IV).

The crop load expressed as the fruit yield to the trunk cross-sectional increment area ratio is a good measure of the reproductive to vegetative 


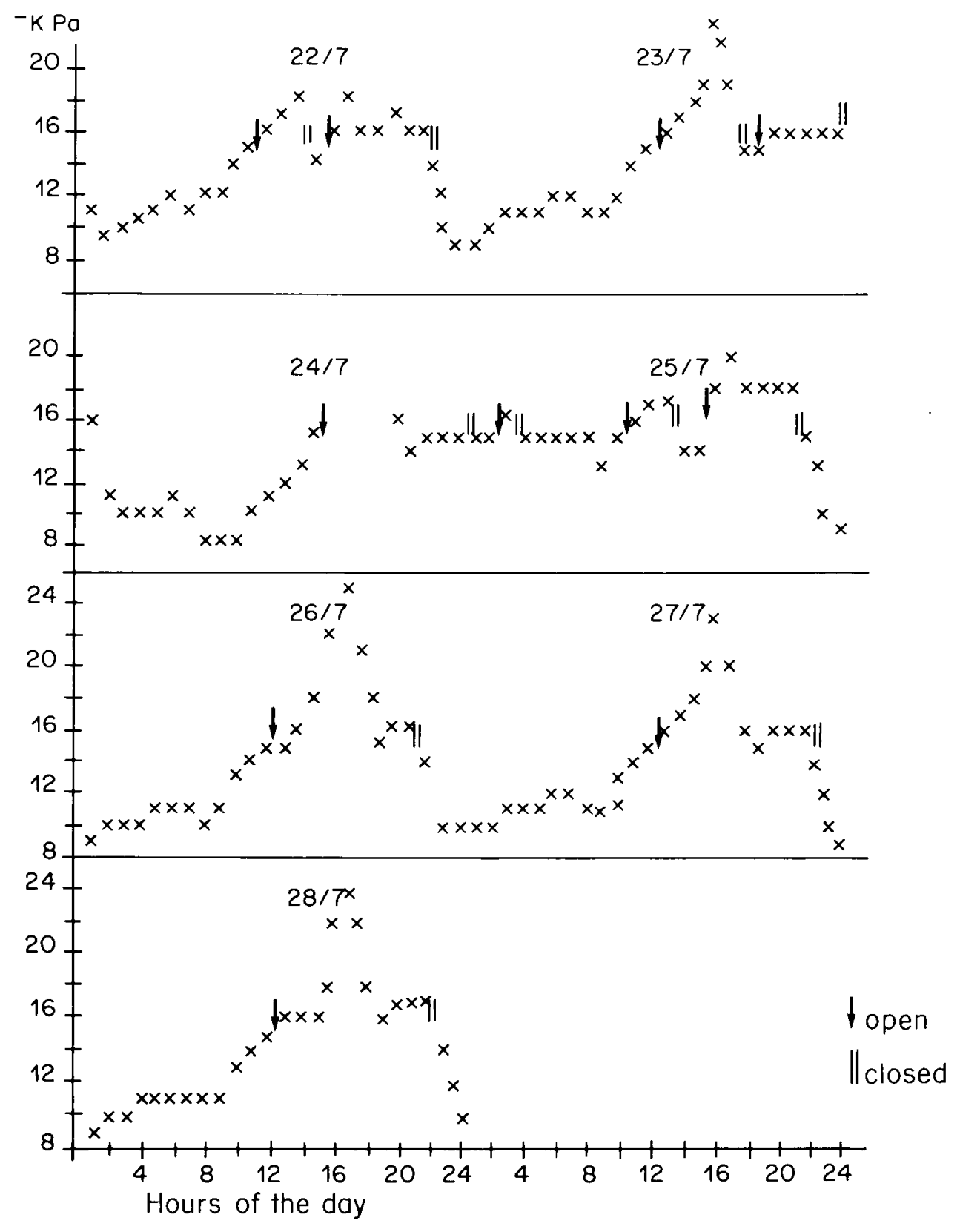

Fig. 2b. Diurnal soil matric potential (SMP) in T2 in 1985.

growth ratio. The crop load was similar and relatively high in all 3 treatments in 1983 (Table V). This shows that the somewhat smaller fruit size in the $-15 \mathrm{kPa}$ treatment obtained in 1983 was not a direct consequence of the fruit load and probably some mechanisms related to the adjustment of the trees to a smaller volume of irrigated soil and a higher SMP in this volume were involved. The crop load of the $-15 \mathrm{kPa}$ threshold treatment in 1984 and 1985 was also slightly higher than in the other 2 treatments. However, the fruit size progressively approached the values of the other 2 treatments (Table V). It seems, therefore, that the trees irrigated at -15
$\mathrm{kPa}$ became smaller but nevertheless more productive and their fruit size did not decrease, as should be expected due to the reduced amount of water applied. It seems that these trees underwent a process of adjustment to root restriction conditions due to the limited volume of irrigated soil. Restricted root volume is known to cause dwarfing and increase the ratio of reproductive to vegetative growth (Lenz, 1967, Richards and Rowe 1967; Moss, 1978; Salomon 1978). This may allow more trees to be planted per ha, induce precocity, reduce operational costs and increase light penetration into the canopy, thereby improving fruit quality. Restricting roots by drip 
Tableau IV. Trunk cross-sectional area increment per tree.

\begin{tabular}{|c|c|c|c|c|}
\hline Treatment & $\begin{array}{l}1983 \\
\left(\mathrm{~cm}^{2}\right)\end{array}$ & $\begin{array}{l}1984 \\
\left(\mathrm{~cm}^{2}\right)\end{array}$ & $\begin{array}{l}1985 \\
\left(\mathrm{~cm}^{2}\right)\end{array}$ & $\begin{array}{l}\text { Total } \\
(1983-1985) \\
\left(\mathrm{cm}^{2}\right)\end{array}$ \\
\hline 1 & 17.2 & 11.9 & 15.9 & $45.0 \mathrm{a}$ \\
\hline 2 & 10.5 & 8.7 & 9.7 & $28.9 b$ \\
\hline 3 & 19.0 & 12.4 & $\begin{array}{l}15.6 \\
\text { LSI }\end{array}$ & $\begin{aligned} & 47.0 \mathrm{a} \\
= & 9.1\end{aligned}$ \\
\hline
\end{tabular}

Significant differences are indicated by the letters $a, b$.

Tableau V. Ratio of reproductive to vegetative growth $\left(\mathrm{kg}\right.$ fruit $/ \mathrm{cm}^{2}$ trunk area increment per tree).

\begin{tabular}{lrrr}
\hline Treatment & 1983 & 1984 & 1985 \\
\hline 1 & & & \\
2 & 10.1 & 7.3 & 6.8 \\
3 & 10.2 & 9.8 & 8.3 \\
\hline
\end{tabular}

irrigation may replace the use of dwarfing rootstocks in areas with dry summers. Furthermore, improvement of yields and fruit quality may be achieved by controlling SMP levels and mineral concentrations at various stages of growth and development.

\section{References}

Assaf, R., Bravdo B. \& Levin I. (1974) Effects of irrigation according to water deficit in two different soil layers, on the yield and growth of apple trees. $J$. Hort. Sci. 49, 53-64

Bravdo B. \& Hepner Y. (1987) Irrigation management and fertigation to optimize grape composition and vine performance. Acta Hortic. 206, 49-67

Elfving D.C. (1982) Crop responses to trickle irrigations. Hort. Rev. 4, 1-48

Lenz F. (1967) Relationships between vegetative and reproductive growth of Washington navel orange cuttings. J. Hort. Sci. 42, 31-39

Levin I., Assaf R. \& Bravdo B. (1979) Soil moisture and root distribution in an apple orchard irrigated by tricklers. Plant Soil. 52, 31-41

Middleton J.E., Proebsting E.L. \& Roberts S. (1979). Apple orchard irrigated by trickle and sprinkle. $A m$. Soc. Agric. Eng. Trans. 582-584

Moss G.I. (1978) Propagation of citrus for future plantings. Proc. Inc. Soc. Citriculture 132-135

Phene C.J. \& Beale O.W. (1976) High frequency irrigation for water nutrient management in humid regions. Soil Sci. Soc. Am. J. 40, 430-436

Proebsting E.L., Middleton J.E. \& Roberts S. (1977) Altered fruiting and growth characteristics of Delicious apple associated with irrigation method. Hort. Sci. 349350

Richards D. (1983) The grape root system. Hort. Rev. 5, 127-168

Richards D. \& Rowe R.N. (1967) Effects of root restriction, root pruning and 6-benzylaminopurine on the growth of peach seedlings. Ann. Bot. 41, 729-740

Salomon E. (1978) Induction of dwarfing and early cropping through root treatments in citrus. Acta Hort. 65,147 